\title{
No Volatility, No Forecasting Power for the Term Spread
}

\author{
Massimo Guidolin and Allison K. Rodean
}

$\mathrm{T}$ he recent disassociation between the term spread and the real growth rate can be explained in part by the finance fundamentals behind the concept of the term spread. The term spread, commonly defined as the difference between the yields on 10-year U.S. government bonds and 3month Treasury bills, can be interpreted as a risk premium: the additional amount of compensation required to commit wealth into long-term investments in the face of unanticipated inflation shocks. The reasoning is simple: Should inflation accelerate unexpectedly, nominal interest rates are likely to promptly increase. While an investor buying T-bills could access higher yields quickly, an investor who has purchased bonds could not and will suffer a loss since the new nominal interest rates are higher than the bond's rate. Because this loss may be substantial if the bond is far from maturity, bond investors require a reward in the form of a term spread. ${ }^{1}$

We can quantify inflation risk by using the volatility of long-term bond yields. If there is substantial inflation risk, investors will tend to revise often their expectations of future inflation rates. This process affects long-term bond prices and causes volatility in their yields.

If inflationary risks decline independently of business cycle conditions, long-term bond yields become less volatile and the quantity of risk declines; this causes the term spread to decrease as well. The table shows this has been true over the past 26 years. In the Volcker era, the average realized (computed using daily yields), annualized volatility on 10-year government bonds had been 3.7 percent with a 2.2 percent term spread. Under Greenspan, the average realized volatility declines to 1.3 percent and the term spread declines to 1.7 percent.

However, the past two years have been characterized by a very low volatility in the bond market ( 0.7 percent) and virtually no term spread (0.04 percent). And the past decade has been characterized by less than half the risk formerly in the bond market, and at the same time the term spread has declined by approximately one-half.

Low or negative term spreads are conventionally seen as harbingers of recession. Between January 2005 and December 2007 , the term spread declined to an average of 0.35 percent per year. Surprisingly, over the same period, real GDP maintained a brisk pace of almost 3 percent per year. Is it surprising the U.S. term spread has stopped forecasting real economic growth? No, because the term spread is a risk premium compensation that declines when risk disappears. For support, we have computed correlations between the term spread and the real GDP growth rate for two subsamples: 1981-94 and 1995$2007 .{ }^{2}$ We find a high and statistically significant correlation in the first, high-volatility subsample, 0.36 ; with sufficient risk, the term spread is positive and varies to reflect anticipations of future business cycles. Over the second, low-volatility subsample the term spread has lost any association to real economic growth: The correlation is essentially zero $(-0.03)$ and is not statistically significant. If the term spread mostly depends on inflationary risk and such risks disappear over time, poor forecasting performance is expected. It is ironic that the very success of Chairmen Greenspan and Bernanke at fighting inflation and anchoring inflationary expectations may have led to a new era in which forecasters and policymakers struggle with the loss of the term spread's predictive power. The business cycle remains difficult to forecast, although with stable inflation, the loss of a forecasting instrument seems a small price to pay.

${ }^{1}$ The term spread also depends on other factors, e.g., the differential liquidity of the short and long term segments of the bond market and, in principle, the uncertainty of future real interest rates. Even though we recognize that these factors are like to be priced in the term spread, we simply assume a direct relationship between the term spread and the variance of excess long-term bond returns.

${ }^{2}$ Consistently with the literature, we apply a lag of 3 quarters in the relationship, i.e., real GDP growth today is predicted by the term spread 3 quarters ago. There has been some recent debate on whether and why the term spread may actual forecast business cycle conditions: See Anderson, R. "Yield Curve Inversions and Cyclical Peaks.” Federal Reserve Bank of St. Louis Monetary Trends, May 2006.

\begin{tabular}{|lccc|}
\hline Date range & $\begin{array}{c}\text { Average } \\
\text { term spread }\end{array}$ & $\begin{array}{c}\text { Average } \\
\text { votility }\end{array}$ & $\begin{array}{c}\text { Number of } \\
\text { months }\end{array}$ \\
\hline $\begin{array}{l}\text { Volcker era } \\
(9 / 1981-7 / 1987)\end{array}$ & 2.187 & 3.695 & 71 \\
$\begin{array}{l}\text { Greenspan era } \\
(8 / 1987-1 / 2006)\end{array}$ & 1.689 & 1.296 & 222 \\
$\begin{array}{l}\text { Bernanke era } \\
(2 / 2006-7 / 2007)\end{array}$ & 0.036 & 0.747 & 23 \\
$9 / 1981-12 / 1994$ & 2.129 & 2.420 & 160 \\
$1 / 1995-7 / 2007$ & 1.220 & 1.153 & 156 \\
\hline
\end{tabular}

